\title{
Georges Didi-Huberman, Kora, Otto Dov Kulka, Pejzaże metropolii śmierci - jako eseje lagrowe? Wyobraźnia i pamięć formul tytułowych wobec formuły anus mundi
}

Miejsca, które zobaczyłem, były zniekształcone, zatarte. Były „nie-miejscami” pamięci (non-lieux de la mémoire). Nie przypominały tego, czym były kiedyśr.

\section{Zapis}

Chciałabym zacząć od nawiązania do zasadniczego tematu czasopisma, w którego sformułowaniu przykuwa uwagę słowo „zapis”. Formuła ta zajmowała już piszących o lagrach, łagrach, obozach. Arkadiusz Morawiec, a przed nim Lesław M. Bartelski² odnosili się do typu narracji po-obozowych, różnicując te w pierwszej i te w trzeciej osobie. Morawiec pisał:

W przypadku konsekwentnego posługiwania się narracją pierwszoosobową, autorka [mowa o Sewerynie Szmaglewskiej i Dymach nad Birkenau - przyp. KKK] - chcąc utrzymać wrażenie obiektywizmu - musiałaby za każdym razem dokumentować swą niezwykle szeroką wiedzę o obozie, której mocą własnego doświadczenia (ponad dwuletniego pobytu w lagrze) nie mogłaby zdobyć: być wszędzie. Wprawdzie wspomina we wstępie o swoim „długim pobycie w Birkenau” [...], jednak duża część

* Dr hab. Katarzyna Kuczyńska-Koschany, prof. nadzw.; Uniwersytet im. Adama Mickiewicza w Poznaniu; Instytut Filologii Polskiej, Zakład Badań nad Tradycją Europejską; ul. Fredry 10, 61-701 Poznań; eadem@amu.edu.pl.

${ }^{1}$ Claude Lanzmann's ,, Shoah”. Key Essays, red. S. Liebman, Oxford University Press, New York 2007, s. 39. Cyt. za: P. Czapliński, Nie-miejsce [hasło] w: Modi memorandi. Leksykon kultury pamięci, red. M. Saryusz-Wolska, R. Traba, współpraca J. Kalicka, Scholar, Warszawa 2014, s. 272. Por. także: C. Lanzmann, Le non-lieux de la mémoire, w: Au sujet de Shoah, le film de Claude Lanzmann, red. B. Cuau, Belin, Paris 1990, s. 280-293.

${ }^{2}$ L.M. Bartelski, Zapis zbrodni, w: tenże: Cień wojny. Eseje, Czytelnik, Warszawa 1983. 
informacji zawartych w książce pochodzić musi z drugiej ręki. Trudno bowiem przypuszczać, aby autorka była bezpośrednim świadkiem orgii esesmanów, odwiedzała męskie baraki czy z bliska obserwowała palenie zwłok w dołach w Birkenau. Stąd nie mniej przekonujący, nie mniej obiektywny, wiarygodny wydaje się panoramiczny obraz obozu Auschwitz, zawarty w pisanych w pierwszej osobie wspomnieniach Anus mundi Wiesława Kielara. Był on bardziej od Szmaglewskiej „wszędobylski”, spędził w Auschwitz-Birkenau ponad cztery lata, jako więzień przeszedł wiele szczebli drabiny obozowej: był tragarzem trupów, wyciągał zwłoki sowieckich jeńców zagazowanych w jednym z bloków, był kapo, był pisarzem (schreiberem), pracował w różnych komandach, dwadzieścia nocy spędził w stehbunkrze. Najistotniejsze wszakże wydaje się to, że kobiety-więźniarki miały mniejsze możliwości poruszania się w lagrze, z racji mniejszego repertuaru zatrudnień. Rodzi się zatem pytanie, czy niemalże bezosobowa narracja Dymów..., osłabiana wprawdzie przez bezpośrednie zwroty narratora (narratorki) do mniej lub bardziej ukonkretnionego „ty”, zwykle współwięźnia, nie jest paradoksalnie mniej obiektywna, wiarygodna aniżeli narracja pierwszoosobowa. Taką wątpliwość odczytać można z postulatu Tadeusza Borowskiego, adresowanego wprawdzie do Zofii Kossak, jako autorki wspomnień z Birkenau pt. Z otchłani: „nie wolno o Oświęcimiu pisać bezosobowo" [to cytat ze słynnej recenzji Alicja w krainie czarów, „Pokolenie” 1947, nr 1, s. 9 - przyp. KKK]³.

Dlaczego ten, dość długi cytat, jest ważny, okaże się w dalszej części tekstu. Na razie jednak przywołam - ku własnemu zdumieniu - Stanisława Lema, który w Terminusie (z tomu Opowieści o pilocie Pirxie) napisał: „Jedno jest pewne: ten zapis - jeśli to zapis - nie jest martwy. Kimkolwiek są ci ludzie - te głosy, te uderzenia - można z nimi mówić. Jeśli się tylko ma odwagę..."4. Te słowa odnieść by można do wielu zapisów obozowych, lagrowych i łagrowych, do tego, co jako literaturoznawcy, historycy, szerzej - humaniści, nazywamy za Romanem Zimandem literaturą dokumentu osobistego ${ }^{5}$, a za Jerzym Jedlickim próbujemy uzgadniać jako „dzieje doświadczone” i/lub „dzieje zaświadczone”.

W moim szkicu proponuję jednak coś innego. Zstąpienie w głąb oksymoronu, jakim wydaje się być formuła ,eseje lagrowe”. Już eseje zagładowe to rzadkość.

\footnotetext{
${ }^{3}$ A. Morawiec, Literatura $w$ lagrze, lager w literaturze. Fakt - temat-metafora, Wydawnictwo Akademii Humanistyczno-Ekonomicznej, Łódź 2009, s. 189-190.

${ }^{4}$ Cyt. za: A. Gajewska, Zagłada i gwiazdy. Przeszłość w prozie Stanisława Lema, Wydawnictwo Naukowe UAM, Poznań 2016, s. 212.

${ }^{5}$ R. Zimand, Diarysta Stefan Ż., Ossolineum, Wrocław 1990.

${ }^{6}$ J. Jedlicki, Dzieje doświadczone i dzieje zaświadczone, w: Dzieło literackie jako źródło historyczne, pod red. Z. Stefanowskiej i J. Sławińskiego, Czytelnik, Warszawa 1978, s. 344-371.
} 
Primo Levi, Jean Améry ${ }^{7}$, Maurice Blanchot ${ }^{8}$, Bogdan Dawid Wojdowski ${ }^{9}$. Nie znajdziemy ich wielu. Mają swoją wstępnie opisaną specyfikę ${ }^{10}$. Lagrowe? Czyli pewna, swoista odmiana eseistyki miejsca, geoeseistyki? Czy raczej próbowanie (z francuskiego essayer) nie-miejsca? ${ }^{11}$

Dwaj myśliciele - celowo nie nazywam ich filozofami - postanowili, niezależnie od siebie, zapisać doświadczenie przestrzeni lagru, niezapisywalne, a stawiające granicę wyobraźni. Eseje Ottona Dova Kulki (rocznik 1933) z tomu Pejzaże metropolii śmierci oraz Kora Georges'a Didi-Hubermana (autora Obrazów mimo wszystko) ${ }^{12}$ twórczo dyskutują z tytułową formułą książki Wiesława Kielara (1919-1990) Anus mundi, wydanej w roku 1966 (data ukończenia zapisana przez autora to 21 stycznia 1966) ${ }^{13}$. Czynią to na dwa różne sposoby, pomiędzy którymi można jednak dostrzec pewne tertium comparationis - ujęcie rewersowe w stosunku do „odbytu świata”. Próbują pisać esej, czyli rzecz równie dziwną jak (ongiś dla Adorna) wiersz, wiersz Paula Celana, po Auschwitz.

\footnotetext{
${ }^{7}$ Myślę tu zwłaszcza o eseju Mein Judentum, a także tomach Poza wina i kara i O starzeniu się.

${ }^{8}$ Por. M. Blanchot, Niezniszczalne. Być Żydem, przeł. W. Błońska, „Literatura na Świecie” 1996, nr 10, s. 59-68.

9 B. Wojdowski, Judaizm jako los, „Puls” 1993, nr 3. Na ten temat por. K. Kuczyńska-Koschany, Eseiści kondycji żydowskiej - po Zagładzie: Maurice Blanchot i Bogdan Dawid Wojdowski, „Poznańskie Studia Polonistyczne. Seria Literacka” (w druku).

${ }^{10} \mathrm{Na}$ ten temat zob. A. Ubertowska, Holokaust. Auto(tanato)grafie, Wydawnictwo IBL PAN, Warszawa 2014.

${ }^{11} \mathrm{Na}$ ten temat zob. P. Czapliński, Nie-miejsce, s. 270-272. Czapliński nazywa nie-miejsce - „kategorią z zakresu antropologicznej nad przestrzenią” (s. 270), definiowaną, między innymi, w odniesieniu do pamięci i tożsamości jednostkowej. Poznański antropolog wywodzi to pojęcie od Tomasza Morusa (Utopia, 1516), odróżniającego greckie ou-tópos od eu-tópos; wskazuje na Michela de Certeau jako pierwszego, który użył w dziele Wynaleźć codzienność (1980) terminu non-lieu, tej szczególnej nazwy własnej „zagłębienia lub nie-miejsca wydrążonego przez prawo innego", przeciążonego zindywidualizowaną pamięcią i nie dającego się oswoić. Kolejne, najbardziej znane, zastosowanie pojęcia to esej Marca Augé Nie-miejsca. Wprowadzenie do antropologii hipernowoczesności (1995), który „nazwał w ten sposób miejsca pozbawione pamięci i niestanowiące locum władzy, a mimo to niedające się oswoić i niesprzyjające suwerenności powszechnej”. Najważniejsza dla moich rozważań jest następująca konstatacja Czaplińskiego: „W ramach polemiki z koncepcją Pierre'a Nory (i niezależnie od rozważań Augégo) Claude Lanzmann stwierdził, że przybywając do dawnych obozów koncentracyjnych, zastawał «nie-miejsca pamięci» [...]. «Miejsca, które zobaczyłem, były zniekształcone, zatarte. [...] Nie przypominały tego, czym były kiedyś». [...] można sądzić, że Lanzmannowi chodziło o radykalną niezdolność obozu-miejsca pamięci do budzenia pamięci wlaśnie, czyli unaocznienia znaczeń centralnego miejsca, jakim w obozie była komora gazowa, oraz uświadomienia różnicy między pozaobozową przestrzenią życia i obozową przestrzenią śmierci” (s. 272, podkr. KKK).

${ }^{12}$ G. Didi-Huberman, Obrazy mimo wszystko, przekł. M. Kubiak Ho-Chi, Universitas, Kraków 2008.

${ }^{13}$ Wydanie 1 - 1966, wydanie 2 - 1972, wydanie 3 - 1980.
} 


\section{Anus mundi}

Już sama formuła anus mundi ma swoją ciekawą i chyba niekoniecznie bardzo znaną historię. We wstępie do książki Wiesława Kielara, przypomnijmy: więźnia oświęcimskiego nr 290, jednego z najniższych numerów w Auschwitz spośród tych, którzy przeżyli, można przeczytać, iż to właśnie Birkenau/Brzezinkę nazwał odbytnicą świata lekarz SS Hauptsturmführer Thilo (po selekcji i uśmierceniu 800 kobiet):

Opinię tę - czytamy dalej - odnotował jego kolega, także lekarz SS, profesor uniwersytetu, doktor medycyny i filozofii, Johann Paul Kremer po datą 5 września 1942 roku, pisząc dosłownie: „Dziś w południe przy akcji specjalnej z obozu kobiecego: coś najokropniejszego z okropności. Hauptsturmführer Thilo, lekarz garnizonowy, miał rację mówiąc mi dzisiaj, iż znajdujemy się przy anus mundi (odbytnicy świata) ${ }^{14}$.

Mieczysław Kieta, autor wstępu do książki Kielara, tak tłumaczy tę formułę, wypowiedzianą podczas masowego uśmiercania, powołując się przy tym na Antoniego Kępińskiego:

Anus mundi w ustach lekarza garnizonowego SS Heinza Thilo było dla tego miejsca określeniem wyrażającym z jednej strony obrzydzenie i grozę, jakie budził w każdym obserwatorze obóz koncentracyjny [...], z drugiej strony uzasadniało istnienie obozu koniecznością oczyszczenia świata. W koncepcji hitlerowskiego obozu zagłady - poza bezpośrednim celem polityczno-ekonomicznym, polegającym na jak najbardziej efektywnym i najtańszym wyniszczeniu wroga - miało ono sens głębszy; było nim oczyszczenie rasy germańskiej z tego wszystkiego, co nie zgadzało się $\mathrm{z}$ ideałem germańskiego nadczłowieka (AM, 13-14).

Otóż pierwodruk tekstu Kępińskiego, zatytułowanego Anus mundi, ukazał się w „Przeglądzie Lekarskim” w roku 1965, w numerze 1. Mieczysław Kieta zaś informuje, że tytuł Anus mundi ,został przyjęty przez Wydawnictwo jako tytuł wspomnień Kielara” - między innymi (chociaż nie tylko) dlatego że „w najbardziej lapidarny sposób wyraża on funkcje hitlerowskiego obozu zagłady" (AM, 14). Zatem formuła anus mundi nie jest autorskim wyborem Kielara, lecz pochodną refleksji Kępińskiego, który napisał, iż „Obozy zagłady odsłoniły prawdę o człowieku, której dotychczas ludzkość nie może strawić” (RO, czwarta strona okładki).

${ }^{14}$ W. Kielar, Anus mundi, wyd. 3, Wydawnictwo Literackie, Kraków 1980, s. 13. Dalej jako AM, wraz z numerem strony. Por. też: W. Sofsky, Ustrój terroru. Obóz koncentracyjny, przekł. M. Łukasiewicz, Żydowski Instytut Historyczny im. Emanuela Ringelbluma, Warszawa 2016. 
W Refleksjach oświęcimskich Kępińskiego, wydanych w 2005 roku w opracowaniu Zdzisława Jana Ryna, są dwie duże części tematyczne:

W pierwszej części, zatytułowanej Anus mundi, zamieszczono artykuły poświęcone rzeczywistości obozowej i jej traumatycznym skutkom. Były one drukowane za życia Autora, a potem zebrane w książce Rytm życia. Część druga, Homo homini lupus est, zawiera artkuły o szerszej tematyce [...] oraz dwa niepublikowane maszynopisy $\mathrm{z}$ lat sześćdziesiątych ${ }^{15}$.

W artykule zatytułowanym Anus mundi Antoni Kępiński nazywał tę formułę „dosadną” i pisał między innymi:

W koncepcji hitlerowskiej obozy zagłady - poza bezpośrednim celem polityczno-ekonomicznym, polegającym na jak najbardziej efektywnym i najtańszym wyniszczeniu wroga - miały sens głębszy; było nim oczyszczenie rasy germańskiej z tego wszystkiego, co nie zgadzało się z ideałem germańskiego nadczłowieka. Przyświecała mu daleka wizja świata ludzi pięknych, silnych, zdrowych, świata, w którym nie byłoby miejsca dla chorych, kalek, nienormalnych psychicznie, skażonych krwią żydowską czy cygańską.

Dla tego „pięknego” celu trzeba było przejść przez wstrętne okropności obozów koncentracyjnych. Nic też dziwnego, że służba w obozie była traktowana na równi ze służbą frontową, choć esesmani pewnie woleli być bohaterami w obozie niż na froncie. Prawo zachowania życia jest na ogół silniejsze od ideologii; jeszcze lepiej, gdy szczytną ideologią można wytłumaczyć własne tchórzostwo. Zdarzali się jednak tacy, wprawdzie nieliczni, którzy nie wytrzymywali upodlenia służby w obozie koncentracyjnym i wybierali front lub samobójstwo. Większość uspokajała się alkoholem i poczuciem dobrze wypełnionego obowiązku dla dobra ojczyzny i wielkiej idei (RO, 11-12).

Kępiński zwraca uwagę, że ci, „którzy byli przeszkodą, materiałem przeznaczonym na zagładę, by sobą nie zanieczyszczał więcej nowego świata", różnie reguły tego świata przyjmowali: fatalistycznie - jako los nieodwracalny, pragmatycznie - jako możliwość naśladowania z horyzontem ewentualnego przeżycia, i jeszcze inaczej - dla tej najrzadszej postawy nie znajduję właściwego określenia, zatem zacytuję:

Byli też tacy, którzy mimo głodu, pragnienia, zimna, bólu, poniżenia godności ludzkiej potrafili jakby oddalić się od swego cierpienia i nie myśleć tylko o tym, aby

${ }^{15}$ Z.J. Ryn, Wstęp, w: A. Kępiński, Refleksje oświęcimskie, wybór i wstęp Z.J. Ryn, Wydawnictwo Literackie, Kraków 2005, s. 8. Dalej jako RO wraz z numerem strony. 
zdobyć coś do jedzenia, by przestało być zimno czy gorąco, by nie bolało znękane ciało. Imperatyw biologiczny jest niesłychanie silny i niemałego trzeba wysiłku woli, by nie myśleć o chlebie, gdy się jest głodnym, o wodzie, gdy chce się pić, lub o bolącym miejscu, gdy boli. Wysiłek ten jednak był konieczny dla zachowania wewnętrznej swobody - wolnej przestrzeni, w której można było swobodnie myśleć, marzyć, planować, powziąć decyzję, uwolnić się od koszmaru chwili obecnej. Jeśli w życiu obozowym, w tym anus mundi, tyle było poświęcenia, odwagi, miłości człowieka, a więc zjawisk w tych warunkach - zdawać by się mogło - zgoła niemożliwych, to właśnie dzięki tej wewnętrznej wolności $(\mathrm{RO}, 15)$.

Literatura dokumentu osobistego dawała asumpt do parafrazy formuły anus mundi w tytule dzieła historiograficznego. Monografia Zygmunta Zonika, więźnia Buchenwaldu, uczestnika marszów śmierci, badacza i dokumentalisty, traktująca o ewakuacji i wyzwoleniu lagrów, wydana w roku 1988, nosi tytuł Anus belli (odbytnica wojny). Zonik nie odwołuje się do Kielara w żadnym z miejsc swej ponadczterystustronicowej książki; pisze tylko - „oni nie musieli zabijać” - mając na myśli ostatnie czyny sprawców i mordowane dziesiątkami tysięcy ofiary wojny. Zbieżność tych tytułów jest jednak głęboko zastanawiająca i nie wynika tylko, jak sądzę, z przedwojennego wykształcenia z jego obowiązkową znajomością łaciny, na które nakłada się osobiste i długotrwałe doświadczenie obozowe ${ }^{16}$.

Są one, obydwie formuły, i anus mundi, i anus belli, semantycznie pokrewne ,jądru ciemności” (,sercu ciemności”) Josepha Conrada ${ }^{17}$, a jednocześnie skrajnie od niego różne. Bo odnoszą się do sfery dotychczas tabuizowanej, nie poddawanej zabiegom metaforyzacyjnym. Myśląc o ,jądrze ciemności”, możemy jeszcze pielęgnować złudzenia estetyczne Europejczyków albo złudzenie złudzenia (dzisiaj - w epoce postkolonialnej już tego nie robimy, ale trwało długo, zanim zaczęliśmy myśleć o ludobójstwie w Afryce jako o dokonywanym w tym, a nie w innym świecie); gdy czytamy tytuł - anus belli czy anus mundi, o żadnych złudzeniach nie może być mowy.

I to mnie właśnie zafrapowało - jak do tego ma się esej, dziedzina niuansu par exellence? Kto mówi, kiedy mówi eseista? Bo ani sprawca, ani ofiara, których motywacji dociekają Kępiński, Kielar, Borowski, Szmaglewska. Ani - w każdym razie nie do końca - świadek. Kto zatem? I dzięki czemu jest jeszcze kimś innym? I dlaczego w obydwu wybranych esejach powtarzają się jak mantra dwa słowa: pamięć i wyobraźnia.

${ }^{16}$ Z. Zonik, Anus belli. Ewakuacja i wyzwolenie hitlerowskich obozów koncentracyjnych, PWN, Warszawa 1988.

${ }^{17}$ Zob. zwłaszcza najnowsze polskie przekłady: J. Conrad, Jądro ciemności, przeł. J. Polak, posł. opatrzył P. Czapliński, Vesper, Poznań 2009; J. Conrad, Jądro ciemności, przeł. M. Heydel, Znak, Kraków 2011. 


\section{Kora}

Paul Celan, którego Todesfuge była przyczyną bodaj największej dyskusji o stosowności pisania wierszy po Zagładzie, dyskusji poety i filozofa, z której zwycięska, lecz i odmieniona, wyszła poezja, także poezja samego Celana, a którego rodzice zginęli w rumuńskim obozie masowej eksterminacji w Transnistrii ${ }^{18}$, pisał, że wiersze są trochę lepszą korą platanów. Wskazywał na szczególną cechę kory tych drzew, która wygląda jak poraniona; nieco podobne cechy przypisuje Georges Didi-Huberman korze zerwanej z brzóz w Brzezince: „patrzyłem na trzy strzępy kory jak na trzy litery pisma sprzed alfabetu”; ,trzy strzępy o szarej, niemal białej nawierzchni”, „różowe jak mięso”, odpadające zwojami niczym resztki spalonej książki ${ }^{19}$.

Kora pyta synekdochicznie o historię uśmiercania, o obecność niewyobrażalnego w organicznym: teoretyk, który jest bezradny, pisze esej. Na początku tego eseju bada fakturę kory (materii śmiertelnej), na końcu zapisuje rzeczy o wadze wyjątkowej - pokazuje kolejny „obraz mimo wszystko”:

Co kora mówi mi o drzewie. Co drzewo mówi mi o lesie. Co las, brzozowy las, mówi mi o Birkenau. Rzecz jasna, ten obraz, podobnie jak pozostałe, to tylko drobiazg. Drobiazg, powierzchowny drobiazg: błona, osadzające się halogenki srebra, materializujące się piksele. Wszystko zawsze na powierzchni, układane warstwami. Techniczne powierzchnie świadczące jedynie o powierzchni rzeczy. Co mówi mi o głębi, do jakiej głębi to dociera? Większość obrazów - jestem tego świadomy - pozostaje bez konsekwencji. [...]

Nie wszystkie jednak obrazy pozostają bez konsekwencji dla innych. Są też takie - jak choćby obrazy wykonane przez członka Sonderkommando w Birkenau - które okazują się aktem zbiorowym, a nie zwykłym prywatnym trofeum czy bibelotem. Zdarzają się powierzchnie, które zmieniają głębię otoczenia. Filozofowie czystej idei, mistycy Świętego Świętych myślą o powierzchni wyłącznie jako o makijażu, kłamstwie: tym, co ukrywa prawdziwą istotę rzeczy. Zatem pozór kontra esencja, wygląd kontra substancja. Ale można też powiedzieć, że substancja istniejąca poza powierzchnią to tylko metafizyczne złudzenie. Można powiedzieć, że powierzchnia to coś, co odpada od rzeczy: co pochodzi bezpośrednio od nich, oddziela się, a więc pochodzi od rzeczy. I co oddziela się, aby wyjść nam na spotkanie, stanąć nam przed oczami, jak strzępy kory drzewa. Jeśli tylko schylimy się, żeby podnieść parę kawałeczków (K, 85-87, podkr. GDH).

\footnotetext{
${ }^{18} \mathrm{Na}$ ten temat zob. T. Snyder, Czarna ziemia. Holokaust jako ostrzeżenie, przekł. B. Pietrzyk, Znak Horyzont, Kraków 2015.

${ }^{19}$ G. Didi-Huberman, Kora, przeł. T. Swoboda, W podwórku, Gdańsk 2013, s. 7-8. Dalsze przywołania jako K, wraz z numerem strony.
} 
To, co dzieje się w zakończeniu eseju Didi-Hubermana, jest kluczowe, by jakkolwiek dotknąć (właśnie dotknąć, a nie pojąć czy rozstrzygnąć) doświadczenie Zagłady i lagru jako owego nie-miejsca, gdzie się również dokonywała. Nagle okazuje się, że „Kora nie jest mniej prawdziwa od pnia” (K, 87), że jest „nieregularna, nieciągła, urozmaicona”, jest nieczystością, przygodnością, różnorodnością, obfitością, względnością - a jednocześnie pochodzi z istoty rzeczy. I tu pojawiają się sformułowania zasadnicze w odniesieniu do tematu ,zapisu”: otóż kora - pisze eseista ,sytuuje się gdzieś na granicy ulotnego pozoru i ocalalego zapisu. Albo właśnie oznacza zapisany pozór, całą ulotność naszych życiowych decyzji, naszych aktywnych i biernych doświadczeń" (K, 88). Kilka prawie przypadkowych zdjęć - ani olśnienie, ani przygnębienie - tak postrzega swoje samopoczucie w Birkenau Didi-Huberman. I nagle: te fotografie okazują się prawie przypadkowe („Parę obrazów to nic jak na taką historię”, K, 90). Eseista wyjaśnia sens tego prawie/pomimo:

Dla mojej pamięci są jednak tym, czym parę strzępów kory dla pnia drzewa: skrawkami skóry, ciałem. Według etymologów francuskie słowo écorce to średniowieczne przedłużenie łacińskiego scortea, oznaczającego ,płaszcz ze skóry”. [...] Klasyczna łacina dokonała cennego rozróżnienia: istnieje nie jedna kora, lecz dwie. Najpierw jest naskórek, czyli cortex. To skrajnie zewnętrzna część drzewa, którą odcinamy, „odkorowujemy” jako pierwszą. Indoeuropejski rdzeń tego słowa - obecny w sanskryckim krtih i krttih - odnosi się zarazem do skóry i noża, który ją rani bądź odcina. W tym sensie kora oznacza graniczną część ciała, w pierwszej kolejności narażoną na cios, na zranienie, na odcięcie i oddzielenie.

Tymczasem na oznaczenie miejsca, w którym przylega ona do pnia - co odpowiada skórze właściwej - lacina stworzyła inne słowo, ujawniające drugie oblicze pierwszego: to słowo liber, oznaczające część kory, która lepiej niż cortex służy za materiał do pisania. Słowo to niejako naturalnie dało więc nazwę owym rzeczom niezbędnym do zapisywania strzępów naszej pamięci: rzeczom zbudowanym z samych powierzchni, z rozciętych kawałków wyciśniętej z drzew celulozy, na której pojawiają się słowa i obrazy. To rzeczy wypadające z naszej myśli, zwane książkami. Rzeczy odpadające przy obdzieraniu ze skóry, kora zestrojonych ze sobą tekstów i obrazów (K, 90-91, podkr. KKK).

Odnaleźć miejsce w nie-miejscu, to udało się najboleśniej francuskiemu eseiście. Że tak się zdarzy dzięki próbie, dzięki esejowi, nie było żadną wiedzą uprzednią, daną z góry, żadnym założeniem. Esej jest, jak wiadomo, największym ryzykiem zapisu, jest bezzałożeniowy i niekonkluzywny. I w dodatku - amorficzny. Nie daje więc żadnego oparcia. Domaga się natomiast granicznej i detalicznej, miejscami reportażowej, uczciwości względem siebie samego: 
Wszedłem na główną wartownię. Sfotografowałem okno wychodzące na rampę selekcji. Mój przyjaciel Henri, który mi towarzyszył - i którego łagodny upór skłonił mnie do odbycia tej podróży - twierdzi, że powiedziałem: „To niewyobrażalne”. Powiedziałem to, oczywiście, powiedziałem to jak wszyscy. Jeśli mam jednak dalej pisać, patrzeć, kadrować, fotografować, wywoływać zdjęcia i myśleć o tym wszystkim, to właśnie po to, aby uczynić to zdanie niepełnym. Należałoby raczej powiedzieć: „To niewyobrażalne, więc muszę to wyobrazić sobie mimo wszystko". Żeby przynajmniej coś przedstawić, przy minimum tego, co możemy o tym wiedzieć.

Patrzyłem, było to niewyobrażalne i zarazem tak proste (K, 36-37, podkr. KKK).

Owo „niewyobrażalne” i ,zarazem proste”, które trzeba sobie wyobrazić mimo wszystko, pozwala dostrzec rzeczy najważniejsze:

Zupełnie inaczej [niż w Auschwitz - przyp. KKK] jest w Birkenau. Tutaj murów już prawie nie ma. Skala jednak nie kłamie i uderza z niesłychaną siłą - siłą grozy i rozpaczy. Ziemia także nie kłamie. Auschwitz upodabnia się dziś do muzeum, podczas gdy Birkenau pozostaje już wyłącznie terenem archeologicznym. Takie w każdym razie sprawia wrażenie, gdy patrzymy na to, co można jeszcze zobaczyć w miejscu, gdzie wszystko uległo zniszczeniu: na przykład popękane, zranione, podziurawione, rozłupane podłoże. To pocięte, pokiereszowane, pootwierane podłoże. To zarysowane, zdruzgotane podłoże, to podłoże budzące krzyk.

Miejsce takie jak to wymaga od zwiedzającego, aby zastanowił się w którymś momencie nad własnym aktem patrzenia $(\mathrm{K}, 31-32)$.

\section{Wyobraźnia po}

Zapisy Ottona Kulki, ocalałego z Auschwitz, „dziecka lagru”, są inne. Jego pamięć i wyobraźnia korygują się nawzajem.

Obydwaj jednak, i Didi-Huberman, i Kulka, jadą do Birkenau. Ten drugi rozpoznaje cechy miejsca, gdzie był, ale jako inny:

Nie była to już jednak ta metropolia śmierci, co kiedyś. Był to pejzaż bardzo melancholijny. Pejzaż brzemienny pustką. Chociaż wszystko tam było, tyle że jak gdyby oddalone. Odsunięte przez spustoszenie, a mimo to bardzo dojmujące. [...] Auschwitz zostało pogrzebane. Było pogrzebane, a mimo to zaborcze, jak przepastny grób od horyzontu po horyzont. Ale wszystko tam było i ja, przynajmniej ja, je rozpoznawałem ${ }^{20}$.

${ }^{20}$ O.D. Kulka, Pejzaże metropolii śmierci. Rozmyślania o pamięci i wyobraźni, przeł. M. Szczubiałka, Wydawnictwo Czarne, Wołowiec 2014, s. 25. Dalej jako PMŚ, wraz z numerem strony. 
Niemota i pustka. Ułomek cegły z krematorium, „czarny i smolący” (PMŚ, 28). „Nie dało się wejść do komory gazowej, ponieważ zapadnięty strop zatarasował wejście" (PMŚ, 30) - zapisuje eseista. Przed bramą Birkenau przypadkowy taksówkarz robi mu zdjęcie jego własną leicą, towarzyszką wędrówki przez pejzaże metropolii śmierci. I tu następuje szczególne wyznanie:

W samolocie, którym rzucało w powietrzu - był to mały samolot - poczyniłem jakieś obłędne zapiski w dzienniku, który zawsze mam ze sobą. Zapiski te powtórzyłem potem w pewnym liście; nie wiem, czy ten list nadal istnieje (PMŚ, 31, podkr. KKK).

Jest ta szczególna różnica pomiędzy Didi-Hubermanem, którego rodzina częściowo zginęła podczas Zagłady, a Kulką, który odtwarza obrazy z Theresienstadt, małej śmierci i jej relacji do wielkiej śmierci, scenę chłosty jako rytuału „systemu życia powszedniego", obrazy z obozu widm - Auschwitz - od jesieni 1944 do zimy 1945 roku. Jest więźniem dawnych pejzaży, stąd niemożność zapisu, kontynuowana w ciągu: „obłędne zapiski” w diariuszu - list - esej:

Pozostałem w metropolii, pozostałem więźniem tej metropolii, niezmiennego prawa, które nie pozwala na ratunek, naruszenie straszliwej „sprawiedliwości”, na mocy której Auschwitz musi pozostać Auschwitz. Dlatego niezmienne prawo nadal mnie obowiązywało i nadal tkwiłem w jego władzy, o czym w istocie się przekonałem, wróciwszy tam dziesiątki lat później. Kiedy wróciłem i spełniłem ostatnie zobowiązanie, którego nie miałem „zaszczytu” spełnić przedtem - kiedy więc zstąpilem w przetrwałe ruiny, ruiny komory gazowej i krematorium, wypełniło się niezmienne prawo, „ostateczny sens” [...] wybrzmiał i zakończyła się odyseja, w której byłem niezbywalnie obarczony tym miejscem i z nim złączony (PMŚ, 66, podkr. KKK).

Może najważniejszą kwestią dotyczącą formy eseju Kulki jest jego amorficzność. Widniejąca w bogactwie form, w ich nadmiarze. Wiersze, proza, fragmenty wspomnieniowe, reportażowe, zapiski różnego typu datowane i z różnych miejsc, senne i doświadczone na jawie, wyodrębnione przez tytuły. Słowem: redundancja. U Didi-Hubermana mamy wrażenie nakładania się cząstek, zachodzenia na siebie, korowatości. Tu - wręcz przeciwnie, pokawałkowania. Ale istnieje jakiś element wiążący. Nieustanne poczucie déjà $v u$, towarzyszące autorowi w najmniej spodziewanych miejscach: w Stutthofie, w Jerozolimie, w Pradze; paradoksalny błękit letniego nieba w obozie, od którego jedenastoletni chłopiec, potem dojrzały, wreszcie stary mężczyzna, nie może uciec:

Jedynym niepokalanym błękitem, przewyższającym wszelką inną barwę, zapisanym w mojej pamięci jako barwa lata, barwa spokoju, barwa zapomnienia - chwili zapo- 
mnienia - jest błękit polskiego lata 1944 roku. I w życiu tego mężczyzny, który jako chłopiec był częścią tego lata, wszystko to na zawsze zostanie kamieniem probierczym piękna, którego nie znalazł w żadnym innym poznanym pejzażu ani zapewne nie znajdzie w żadnym takim, jaki jeszcze będzie mu dane oglądać - jak to się mówi - aż po kres dni swoich. [...] nie mam cienia wątpliwości, że będę tam wracał. Ten powrót nawet jeśli jest oddzielony od posępnego powrotu, od którego nie ma ucieczki, sam jest również powrotem, od którego nie ma ucieczki. Ta barwa jest barwą dzieciństwa, barwą niewinności i barwą piękna. I również to jest niezmiennym prawem, od którego nie ma ucieczki. Nie ma ucieczki od piękna, od poczucia piękna u szczytu potęgi i w samym sercu wielkiej śmierci, która rządzi wszystkim (PMŚ, 110-111).

\section{Konkluzje}

Analogicznie do postpamięci Marianne Hirsch można w nowszej eseistyce lagrowej mówić o postwyobraźni, o tym, co wydarza się w eseju po Auschwitz, analogicznie zaś do kategorii auto(tanato)grafii (Derridiańskiej, modyfikowanej przez Aleksandrę Ubertowską) - o eseistyce auto(tanato)imaginacyjnej.

Jeśli jednak postpamięć to kategoria, w którą jest się niejako pokoleniowo wrzuconym/wrzuconą, postwyobraźnia, wyobraźnia odmieniona w eseistyce (a także w poezji) po Auschwitz (czy raczej, częściej - po Birkenau), okazuje się kategorią jednostkową, wymaga granicznego i pojedynczego wysiłku, wysiłku na granicy ludzkich możliwości intelektualnych.

W postwyobraźni obóz nie jest już tożsamy z formułą anus mundi. Nie dokonuje się ani rozumiane fizjologicznie i eugenicznie „oczyszczenie”, ani tym bardziej ideologiczne katharsis. Lecz ten rzadki moment, uchwycony przez Didi-Hubermana - współistnienia niewyobrażalnego i jego ledwie wyobrażalnego - także dla samych eseistów: zapisu.

\section{Bibliografia}

Améry Jean, O starzeniu się. Bunt i rezygnacja. Podnieść na siebie rękę. Dyskurs o dobrowolnej śmierci, przeł. i przedm. opatrzył Bogdan Baran, Czytelnik, Warszawa 2007.

Améry Jean, Poza wina i kara. Próby przełamania podjęte przez złamanego, przeł. Ryszard Turczyn, posł. opatrzył Piotr Weiser, Homini, Kraków 2007.

Bartelski Lesław Marian, Cień wojny. Eseje, Czytelnik, Warszawa 1983.

Blanchot Maurice, Niezniszczalne. Być Żydem, przeł. Wanda Błońska, „Literatura na Świecie” 1996, nr 10, s. 59-68.

Claude Lanzmann, Le non-lieux de la mémoire, w: Au sujet de Shoah, le film de Claude Lanzmann, red. Bernard Cuau, Belin, Paris 1990, s. 280-293. 
Claude Lanzmann's „Shoah”. Key Essays, red. Stuart Liebman, Oxford University Press, New York 2007.

Conrad Joseph, Jądro ciemności, przeł. Jędrzej Polak, posł. opatrzył Przemysław Czapliński, Vesper, Poznań 2009.

Conrad Joseph, Jądro ciemności, przeł. Magda Heydel, Znak, Kraków 2011.

Czapliński Przemysław, Nie-miejsce [hasło] w: Modi memorandi. Leksykon kultury pamięci, red. Magdalena Saryusz-Wolska, Robert Traba, współpraca Joanna Kalicka, Wydawnictwo Naukowe Scholar, Warszawa 2014, s. 270-272.

Didi-Huberman George, Obrazy mimo wszystko, przekł. Mai Kubiak Ho-Chi, Universitas, Kraków 2008.

Gajewska Agnieszka, Zagłada i gwiazdy. Przeszłość w prozie Stanisława Lema, Wydawnictwo Naukowe UAM, Poznań 2016.

Jedlicki Jerzy, Dzieje doświadczone i dzieje zaświadczone, w: Dzieło literackie jako źródło historyczne, pod red. Zofii Stefanowskiej i Janusza Sławińskiego, Czytelnik, Warszawa 1978, s. $344-371$.

Kępiński Antoni, Refleksje oświęcimskie, wybór i wstęp Zdzisław Jan Ryn, Wydawnictwo Literackie, Kraków 2005.

Kielar Wiesław, Anus mundi, wyd. 3, Wydawnictwo Literackie, Kraków 1980.

Kulka Otto Dov, Pejzaże metropolii śmierci. Rozmyślania o pamięci i wyobraźni, przeł. Michał Szczubiałka, Wydawnictwo Czarne, Wołowiec 2014.

Morawiec Arkadiusz, Literatura w lagrze, lager w literaturze. Fakt-temat-metafora, Wydawnictwo Akademii Humanistyczno-Ekonomicznej, Łódź 2009.

Snyder Timothy, Czarna ziemia. Holokaust jako ostrzeżenie, przekł. Bartłomiej Pietrzyk, Znak Horyzont, Kraków 2015.

Sofsky Wolfgang, Ustrój terroru. Obóz koncentracyjny, przekł. Małgorzata Łukasiewicz, Żydowski Instytut Historyczny im. Emanuela Ringelbluma, Warszawa 2016.

Ubertowska Aleksandra, Holokaust. Auto(tanato)grafie, Wydawnictwo IBL PAN, Warszawa 2014. Wojdowski Bogdan, Judaizm jako los, „Puls” 1993, nr 3, s. 61-78.

Zimand Roman, Diarysta Stefan Ż., Ossolineum, Wrocław 1990.

Zonik Zygmunt, Anus belli. Ewakuacja i wyzwolenie hitlerowskich obozów koncentracyjnych, PWN, Warszawa 1988.

Katarzyna Kuczyńska-Koschany

Georges Didi-Huberman, Bark, Otto Dov Kulka, Landscapes

of the Metropolis of Death as lager essays? Imagination and memory towards the idea of anus mundi

\section{Summary}

The article is an attempt at interpretation of two essays, which may be called „lager” essays. These are Bark written by G. Didi-Huberman and Landscapes of the Metropolis of Death written by O.D. Kulka, their books are deeply related as the negation or at least as the questioning of the title of autobiographical book Anus mundi written by W. Kielar. Both authors do not describe 
Nazi concentration camp as ,the anus of the world”. Their imagination is a post-imagination, their memory is a post-memory. In her paper Kuczyńska-Koschany considers the condition of the essay as quasi-genre after the Holocaust, after the genocide and in reference to the experience of a lager.

Keywords: Lager essay; formula anus mundi; post-imagination; post-memory; Georges Didi-Huberman; Otto Dov Kulka; Wiesław Kielar 